\title{
Конаныхина О.В. \\ Оценка экономического вклада природно-ориентированного туризма в развитие Астраханской области
}

Астраханский государственный университет

(Россия, Астрахань)

doi: 10.18411/lj-31-08-2017-11

idsp: 000001:lj-31-08-2017-11

\section{Аннотация}

В статье рассмотрен концептуальный подход к оценке влияния природноориентированного туризма на экономику территории. Рассмотрен комплекс показателей синергизма (синергизм дохода, синергизм выпуска и продаж туристской продукции, синергизм занятости), позволяющих оценить воздействие природно-ориентированного туризма на экономику Астраханской области.

Ключевые слова: устойчивое развитие, природно-ориентированный туризм, показатели синергизма, прямое и косвенное воздействие, Астраханская область.

\section{Abstract}

In article conceptual approach to assessment of influence of the natural focused tourism on territory economy is considered. The complex of indicators of synergism (synergism of income, synergism of release and the sales of tourist production, synergism of employment) allowing to estimate impact of the natural focused tourism on economy of the Astrakhan region is considered.

Keywords: sustainable development, the natural focused tourism, synergism indicators, direct and indirect influence, the Astrakhan region.

Влияние туризма на экономическое развитие любого территориального образования, в том числе и Астраханской области - это результат доходов туристов, связанных с покупкой туристских товаров и услуг. Прямое влияние определяется в виде результата вложения денег туристами в туристские организации, материальное обеспечение работников туристской сферы и создание новых рабочих мест. Средства, потраченные туристами в месте пребывания, образуют доход, который приводит к непрерывной цепочке: расходы - доходы - расходы - доходы и т.д с получением синергетических эффектов. Как универсальная категория, «синергетический эффект» является результатом действия факторов, связанных с его получением, как правило, итогом эффективного комбинирования взаимодействия данных факторов. Исследованием эффектов в экономике занимались многие зарубежные и отечественные ученые. Ричард Кан и Джон Кейнс фактически сформировали определение мультипликатора. Джон Ричард Хикс, Элвин Хансен, Рой Харрод [3] рассматривали условия возникновения и протекания как мультипликативных, так и синергетических эффектов, виды мультипликаторов в экономике, моделирование процессов работы механизма ряда показателей взаимодействия.

Однако, практически исследования в данной сфере посвящены или оценке значения мультипликатора, или определению влияния мультипликативного эффекта по различным сферам деятельности.

Отличие данного исследования от прочих состоит в том, что рассматривается комплекс показателей синергизма (синергизм дохода, синергизм выпуска и продаж туристской продукции, синергизм занятости), которые формируют синергию коммерческих операций в сфере туризма Астраханской области, территория которой не имеет ярко выраженную туристскую привлекательность. По сути дела, процесс распространения синергетического импульса в экономике Астраханской области 
определяет связь динамики показателей устойчивого туризма, в частности природноориентированного, с их статистическими значениями (рис.1).

Понятийный аппарат синергетической теории включает использование термина «синергизм» [3]. При этом под синергизмом туризма понимается результат, возникающий в результате объединения нескольких видов туризма в составе объединенного турпродукта территории в отличие от их реализации отдельно друг от друга. Возникновение синергизма относят к появлению нового качества, в виду определенных количественных и качественных изменений туристского продукта территории [2].

В данном исследовании нас интересует, прежде всего, экономическое воздействие природно-ориентированного туризма, как ведущего направления сферы туризма Астраханской области. Как уже было отмечено выше, оценка экономического воздействия туризма основана на расходах туристов [4].

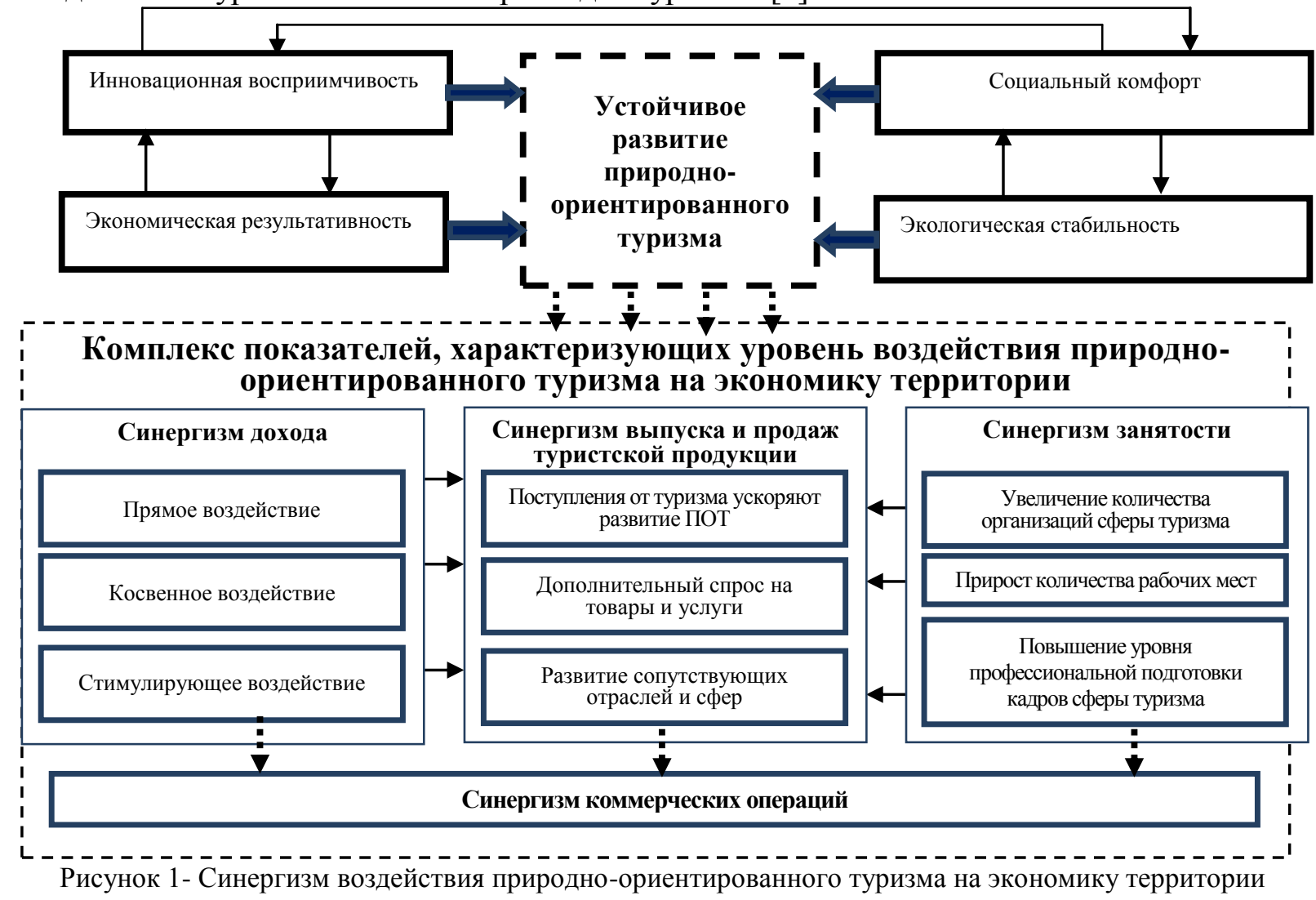

Расчет экономического воздействия расходов туристов производится с помощью системы показателей синергизма, под которыми понимается отношение изменений одного из ключевых экономических показателей, скажем, производства (занятости, дохода) к изменению расходов туристов. Подобные расчеты необходимы руководству Астраханской области в целях:

- принятия решений в отношении дальнейшего развития туристского комплекса;

- планирования и прогнозирования основных социально-экономических показателей территории;

- разработки муниципальных программ, направленных на поддержку сферы туризма;

- совершенствования всей сферы туризма, направленной на повышение уровня туристской привлекательности Астраханской области; усиление экономической взаимосвязи между природно-ориентированным туризмом и другими секторами. 
В современных исследованиях, связанных с расчетами синергетических эффектов, существуют система показателей синергизма, важнейшими из которых являются следующие:

1. Синергизм дохода, включающий три направления воздействия туристских расходов:

- прямого воздействия, предполагающего расходы туристов на отдых (прямой доход средствам размещения, предприятиям общественного питания, музеям, и т.п.);

- косвенного воздействия, предполагающего, к примеру, расходы туристов по бронированию средств размещения, комиссионные туристских операторов и пр;

- стимулирующего воздействия, когда расходы туристов формируют дополнительный доход территории, что приводит к росту потребления, создавая стимулы для развития экономической деятельности.

2. Синергизм выпуска и продаж туристской продукции.

3. Синергизм занятости.

4. Синергизм коммерческих операций, отражающий увеличение товарооборота предприятий и организаций как результата роста расходов туристов.

В зарубежной практике широкое применение в исследовании экономического влияния туризма получил метод «затраты-выпуск» [6]. Применение данного метода позволяет установить взаимозависимости между секторами экономики рассматриваемой территории. Применительно к сфере туризма, сектора, влияющие на ее развитие, могут быть сильно дифференцированы, поэтому реальную картину влияния туризма можно получить, используя модель «затраты-выпуск», разработанную конкретно для этой цели.

Исходная модель «затраты-выпуск» имеет три основных квадранта:

1. В первом квадранте отражается информация о межотраслевых связях, вследствие чего формируется общая картина производственных затрат и распределения продукции на производственные цели всех секторов экономики рассматриваемой территории.

2. Во втором квадранте отражается конечный спрос, показывающий структуру образования валового регионального продукта. Здесь отражаются накопления и текущие инвестиции, личное потребление населения, государственные расходы и т.п.

3. В третьем квадранте отражается стоимостная структура валового регионального продукта, в числе основных стоимостных компонентов которого оплата труда, чистые налоги на производство и валовая прибыль.

$$
* * *
$$

1. Ашинов, С.А. Учет синергетических эффектов при интеграции в индустрии туризма // Успехи современного естествознания. - 2005. - № 3. - С. 52-53.

2. Будумян, Е.В. Синергетический эффект как один из факторов повышения эффективности портфеля инновационно-инвестиционных проектов // Горизонты экономики. 2012. № 4. С. 29-31.

3. Кейнс Дж. М. Избранные произведения. Экономика 1993. -543 с.

4. Степанова, С. А. Развитие туристского комплекса региона на основе повышения инвестиционной привлекательности туристско-рекреационных территорий: дисс. доктора экон. наук: 08.00 .05 / Степанова Светлана Александровна - Санкт-Петербург, 2010. - 403 с.

5. Сычева, Н.В. Туристский ресурс как фактор экономического развития региона/Сычева Н.В. // Вестник ОГУ - 2011. - №8 (127) - С.136-143.

6. Управление развитием туризма в регионе. Опыт реализации Стратегии Республики Карелии / Институт экономики КарНЦ РАН, Под общей ред. Ю.В. Савельева, О.В. Толстогузова. - Петрозаводск: Изд-во Карельского научного центра РАН, 2008. - 141 c. 